\title{
On the Development Trend in Macro-Evolution and Micro-Progress of Law
}

\author{
Linghan Zheng \\ Law School of Hainan University, Hainan, China \\ Email: 863724259@qq.com
}

Received 22 May 2015; accepted 22 June 2015; published 26 June 2015

Copyright (C) 2015 by author and Scientific Research Publishing Inc.

This work is licensed under the Creative Commons Attribution International License (CC BY). http://creativecommons.org/licenses/by/4.0/

cC) (i) Open Access

\begin{abstract}
Law evolution is prior to law progress. Once law progress began, both of them changed simultaneously. When law takes as a collective conception, it makes inner macro-evolution spontaneously. To a large extent, the law itself changes with the social changes. On the contrary, when law is regarded as a unit conception, it proceeds external micro-progress passively. It is depending on the social reason to promote and carefully constructed. The development of traditional law to modern law is development trend in macro-evolution of law. And the independent development from department law to field law is development trend in micro-progress of law.
\end{abstract}

\section{Keywords}

Law Evolution, Macro-Evolution of Law, Micro-Progress of Law, Modern Law, Department Law, Field Law

\section{Introduction}

In the nineteenth century, the England sociologist Spencer, called the father of social Darwinism, first mentioned Social Evolutionism in Social Statics, putting the survival of the fittest in theory of evolution into sociology. In the research of law, Law Evolution, or the alike, is common, because people are apt to accept it which comes from analogy of biological evolution, social evolution, historical evolution and language evolution. Typical researchers of Law Evolution are Japanese scholars. Suiji Chen Zhong (ほづみ陈え) demonstrates in his Law Evolutionism that the form and nature of law are in constant evolving. Suiji Chen Zhong (ほづみ陈え) does this in his "The outline of Jurisprudence" by systemizing society, revenge, the limit of revenge, compensation, detain and publicizing of private right. Muye Yingyi (まきのえいいち) demonstrates it in his "Evolution and progress of the law" with the authority of law, personalization of law and the public right of law. It is undeniable that these famous works of Law Evolution expound it with specific details, but they do not explore its in- 
itiative and passiveness, nor do they touch upon its influence on department law developing into field law. The thesis attempts to describe Law Evolution from macro and micro perspectives. There are many ways to describe Law Evolution. But they have not clarified the real meaning of evolution and progress in biological evolution when they are used in law. To explore the initiative and passiveness of Law Evolution, we should first make clear of inner spontaneity and external passivity. Then, we should further explore their different trends between macro and micro perspectives.

\section{The Relationship of Law Evolution and Law Progress}

With regard to Law Evolution, different scholars convey different thoughts from different respects. Maine thinks that Law Evolution is the change from identity to contract in all social development by far (Maine, 2010). While E. Durkheim thinks that law evolves with social development, changing from Criminal Law (representing mechanical solidarity) to Civil and Commercial Law, Constitutional Law and Administrative Law (representing organic solidarity) (Lv \& Zhou, 1999). Although there are different descriptions about what law is and what it is becoming, there is something common to them. Law Evolution is a gradual process from low level to high level, from simple to complicated and from imperfection to perfection. People often mix up evolution and progress in their researches on Law Evolution. Evolution and progress may mean the same and be replaced by each other in the field of biological evolution. But this is not the same case when it comes to the field of Law Evolution. After all, law is a social phenomenon, not a concrete species. We can just absorb the concept of evolvement. Biological evolution is the outcome of biological gene variants from quantitative change to qualitative change. By analogy, Law Evolution is the outcome of social factors variants from quantitative change to qualitative change. When we describe law Evolution in detail, it is necessary to clarify between evolution and progress.

From literal meaning, “Jin” means moving upward or developing forward ZDIC.NET (2015a), which embodies initiative and spontaneity in general as we call somebody is active or something is developing forward. While "Yan" means popularizing or extending in a logic way ZDIC.NET (2015b), which embodies subjective initiative and objective passivity in general. "Hua” means the changing of nature or form ZDIC.NET (2015c). "Jin" and "Yan" combine with "Hua" to form new words. So, "Jin Hua" (evolution) embodies initiative and spontaneity which means things change from simple to complicate and from low level to high level ZDIC.NET (2015d). And "Yan Hua” embodies subjective initiative and objective passivity ZDIC.NET (2015e) which means things are changed by external factors.

It can be assumed that Law Evolution is spontaneous, reflecting advance of law due to its own reason. While law progress is compulsive, reflecting change of law due to the push from human subjective initiative. When law is used as a collective concept, it mostly reflects macro changes, in which it responds to social changes accordingly. So, evolution suites better to show its spontaneity. When law is used as an individual concept, it mostly reflects micro changes, in which it is carefully established by social rationality. So progress suites better to show its passivity.

\section{Macro Evolution of Law: The Parallel Development of Traditional Law and Modern Law}

When used as a collective concept, law indicates what people call in their common life, not exclusive to a particular department. What is law as a collective concept? "This age-old question has been repeatedly brought up and been answered by serious-minded scholars with all kinds of peculiar or even paradoxical ways” says Hart (Hart, 1996). Although there is no unified definition about it, it does not prevent us from exploring its evolving. Law comes from nothing and first emerges as a collective concept. As a social phenomenon, it evolves with social changes. The macro outcome is that traditional law turns up after common rules ${ }^{1}$ at a certain stage, with modern law ${ }^{2}$ coming into existence afterwards. After that, traditional law and modern law develop parallelly.

At first glimpse, traditional law and modern law are divided by time sequence, because "traditional" and "modern" give people the impression of different stages of time. In fact, they are not distinguished by time se-

\footnotetext{
${ }^{1}$ In this paper, common rules mean the practical convention of the tribe and the order from the leader in primitive society when the law awareness doesn't appear. It doesn't refer to the rules shared by all.

${ }^{2}$ In this paper, modern law means a law system that takes the human rights as the standards. Conversely, the traditional law is a law system that takes the obligation as the standard.
} 
quence. Firstly, all things develop in the change of time. We cannot simply think time is their dividing line therefore. Secondly, the so called traditional law and modern law coexist. If they assume the linear development, traditional law is then replaced by modern law. The latter comer replacing the former one is not the inevitable outcome of evolution. Such as in biological evolution, Manchurian tiger, South China tiger and Bengal tiger are different subspecies of tiger due to different living environment in their evolution. "Compare of their mtDNA D-loop and ND5 shows South China tiger is the oldest of these three tiger subspecies." (Zhang, Zhang, Shen, \& Yue, 2005). This example best prove the above conclusion about evolution outcome. As long as environment permits, they can develop parallelly. Thirdly, calling them traditional law and modern law is to better discuss them in the same discourse system. In that way, what is the criterion to tell them apart? How do they evolve? The answers are that they are distinguished by changes of production mode and come into being in these changes.

Human production mode can be divided into three types. The first is primitive group production mode. The second is small individual production mode, which is self-sufficient natural economy based on individual production. The third is socialized mass production mode, which is market economy based on socialized production. From the first mode comes customs summarized from repeated production, allocation and goods exchange by a common rule. As Engels says in On Housing Problem, "This rule is first referred to as customs and then law." (Engels, 1979). That is to say, the common rule called law restrains people's behavior at the early phase of society. In the second mode, this law is limited to traditional law. But during the second mode developing into the third mode, formulating plenty of separate laws and regulations about economy and society becomes a world historic phenomenon in the field of law. Thus, there comes the modern law composed of economic laws and social laws.

Before the appearing of modern law (symmetric to traditional law), there is just one kind of law with no discrimination of traditional law and modern law. In the first place, with primitive group production mode turning into small individual production mode, common rules evolve into law, but not the traditional law. In the second place, with small individual production mode further turning into socialized mass production mode, there comes a kind of law different to the law before the third mode coming into existence. Consequently, we differentiate them with traditional law and modern law according to the adjustments. After this symmetry, we can call the law between A and B (shown in Figure 1, the same below) traditional law, because laws between A and C are the same with laws between B and C in essence. Traditional law is the outcome of law's macro evolution. Modern law is based on the further evolving of traditional law. Even after the differentiation of traditional law and modern law, modern law does not replace traditional law. It merely continues from $\mathrm{AB}$ to $\mathrm{BC}$ and turns around to $\mathrm{BD}$. Then $\mathrm{BC}$ and $\mathrm{BD}$ realize parallel development and coexistence.

Traditional law is the law mainly used to cope with vested interests (or reserved interests, the same below), while the modern law is used to cope with people's newly-created interests (or increment interests, the same below) (Chen, 2004). The common rule can meet the requirements of the first production mode and the traditional law can meet the requirements in maintaining the second production mode. To maintain the third production mode, both traditional laws and modern laws are necessary, of which the modern laws are more important. Just like the natural rule of "survival of the fittest in natural selection" in biological evolution, while in lawful evolution, the rule is that "survival of the fittest in meeting social need." In the market economy which is based on socialized production, we need the traditional laws which can protect the private vested interests of the owner and sustain the public vested interests, while we also need the modern laws which can adjust the relationship between cooperation and creation, competition and realization and the sharing of newly-created interests. So, when regarded as a collective conception, the trend of evolution of law at macro level is that: traditional law coexists with modern law and continues to evolve.

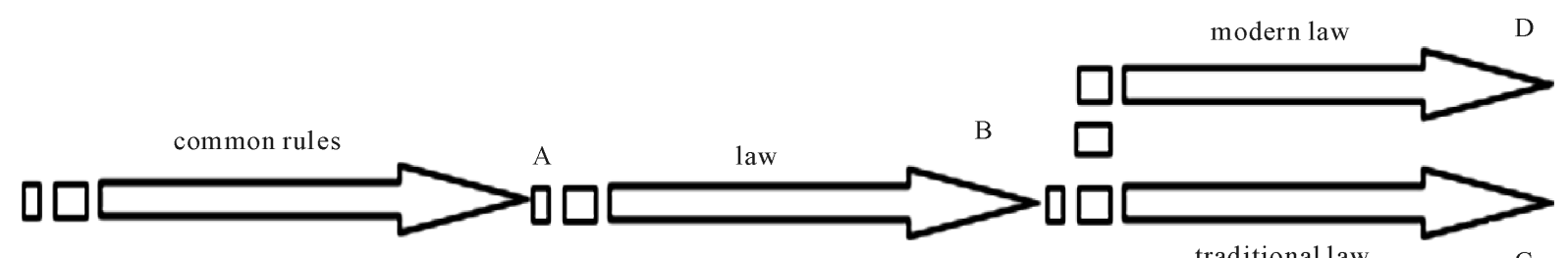




\section{The Trend of Law Micro-Progress: Independent Development from Department Law to Field Law}

Law Evolution emerged prior to law progress which follows the route of Law Evolution. When the law progress starts, they will develop forward simultaneously. When law is regarded as a single conception, namely, the department of law or department law, it specifically refers to the civil law, criminal law or economic law, etc. The subjective initiative of human being plays an important role in the development of law department. On the one hand, we cannot blindly boast the function of human's rationality in social activities considering that law was only created by people; On the other hand, we also cannot ignore people's rationality in social activities that think law was found by people and expressed by lawmakers in a certain form.

We believe that the rule was found somehow at the beginning, and then social people created the law based on it. Namely, the laws (rules), originally objective, came into being spontaneously with the needs of social development; Along with the human needs in life, when human consciousness developed to a certain level, they found such rules and named it "law". At this time, law was a collective conception, which was in the form of concept. After the discovery of the existence of the "law", people were constantly recognizing and exploring its nature, and by virtue of his rationality, the lawmakers created the law to govern the society (at first for the purpose of governance). At this time, the "law" was the combination of the rule was found at the beginning with the social needs derived from human's rationality. We should respect the objective society and confirm the function of rationality in facilitating the micro-process during the macro-evolution of law. The evolution of law not only depends on the inner subtle strength to evolve spontaneously, but on the function of rationality to follow the rule of "meet the social requirements" to promote Law Evolution (in general).

In China, from Lili's Book of Law to the Code of Qing Dynasty, the combination of various laws lasted for more than 2300 years. In the early period of 20th century, when the society underwent a great exchange, Shen Jiaben altered the rule and Wu Tingfang amended the law. They created some department laws such as "Penal Code in Qing Dynasty”, “Criminal Law of Qing Dynasty”, "Draft Civil Law of Qing Dynasty” (Due to some historical reasons), “Commercial Law of Qing Dynasty” by intimating the Civil Law System. What's more, they delivered some court organization laws and lawsuit laws, hence breaking the traditional code-compiling system, from which we see the process of the corresponding department law. Up to now, China's law system with Chinese characteristics consists of 7 departments, including constitution, constitution related law, civil law and commercial law, administrative law, economic law, social law, criminal law, lawsuit and non-lawsuit procedural law. Under this system, "there were 240 current constitution and effective laws, 706 administrative laws and regulations and more than 8600 local laws and regulations till the end of August, 2011”. The Chinese net (2015) From the combination of all laws to the evolution of the department law, the Chinese law tradition has descended from the historical stage and was replaced with law department under various new legal systems. Take the existing department laws into consideration, as a collective conception, the department law changes with the social base or times in the macro evolution. In order to meet the needs of social governance, they were carefully built with people's rationality. As Merryman puts it: "they have to relate economic and social demands with the legislative activities and make laws that could reflect people's will and wishes.” (Merryman, 1984). It is the stimulant of the micro-process of law. There is no denial that the division of the legal department and the formation of the legal system is the crystallization of people's subjective desire and will (Zhuo, 1998).

The micro process of law follows the macro evolution of law to meet the demands of the society in different social stages and different department laws undergo process by virtue of people's rationality. The macro evolution of law contributed to the emergence of traditional law, while the micro process of law resulted in the emergence of traditional department law on the property ownership, such as civil law, administrative law and criminal law and its corresponding lawsuit and non-lawsuit law; When the macro evolution of law led to the existence of modern law, the modern law which reflects the ownership of labor power, like economic law, came into being at the micro process level (by now there is no its corresponding lawsuit and non-lawsuit procedural law). It needs to be specifically pointed out that the constitution is a department law which is the combination of the features of traditional and modern law. These department laws began to develop independently and continue to process.

However, department law is not the final form of the evolution of law. With the change of the social basis, the division of department law cannot meet the requirements of the current situation. Many newly-born "laws" cannot be categorized into any one of the seven department laws. For example, the categorizing of scientific law, 
military law and sports law, and environmental and resources protection law, etc. into any department law cannot meet the demand of division rule in department law. In fact, it is divided and named in accordance with the field of social life, namely, we name the relevant law on science scientific law. Field law is a kind of law that uses the adjusting method and rule in existing department law to solve the specific social issues in a specific field, such as environmental and resources protection law is a kind of law that uses the adjusting method and rule in administrative law, taxation law, lawsuit law to solve the problem of environment and resources protection. Field law is no longer like the traditional department law which must be categorized into a specific one by certain standard. The emergence of field law will constantly challenge the traditional department law, such as the tax law, budget law and finance law in economic laws, and the company law in civil law and commercial law will become the field law to govern their field. Once the law was divided into civil law, criminal law, administrative law, civil lawsuit law and criminal lawsuit law, etc., and in the future the law will gradually develop and is further differentiated and reshuffled (Niu, 2007). Undoubtedly, this trend is moving constantly toward the "field law". As for the field law will replace the department or not is hard to say, but we are optimistic that field law is the trend of the micro process.

\section{Conclusion}

For now, the macro evolution of law follows the route of "law (common rule)-traditional law-modern law" while the law progress follows the route of "law (the combination of various laws)-departmental law-field law". The law in the form of common rule turned into traditional law by means of macro evolution. And based on the traditional law, the modern law emerged. The law in the form of the combination of various laws developed into departmental law by means of micro process. Based on departmental law, the field law emerged. No matter how the law evolves or develops, the traditional law will not be replaced by modern law, and departmental law will not be replaced by the field law. In fact, they will coexist. What we should pay attention is that: in the process of the traditional laws' evolution into modern laws, the obligation standard law becomes right standard law; and in the process of the departmental laws' processing into field law, the law which is "large and comprehensive" turns into "typical and fine". Just like the natural rule of "survival of the fittest in natural selection" in biological evolution, while in lawful evolution, the rule is that "survival of the fittest in meeting social needs."

We can provide a thinking mode for the study of category of laws through the argument above. For example, when a new law that emerges in practice cannot be categorized into any kind of departmental law, we should recognize the existence of the field law rather than directly put a field law into certain departmental law; In practice, when we are coping with legislation, we should make clear that it is traditional or modern law, for it relates to whether the items in the law stick to the obligation standard or right standard.

\section{References}

Maine (2010) Ancient Law (p. 112). Translated by J. Y. Xu. Beijing: The Commercial Press.

Lv, S. L., \& Zhou, S. Z. (1999). Durkheiml Sociology of Law and Law and Social Development. Law and Social Development, 1,1 .

ZDIC.NET (2015a). http://www.zdic.net/z/25/js/8FDB.htm

ZDIC.NET (2015b). http://www.zdic.net/z/1d/js/6F14.htm

ZDIC.NET (2015c). http://www.zdic.net/z/16/js/5316.htm

ZDIC.NET (2015d). http://www.zdic.net/c/b/155/340706.htm

ZDIC.NET (2015e). http://www.zdic.net/c/4/14C/329882.htm

Hart, H. L. A. (1996). The Concept of Law (p. 1). Translated by W. X. Zhang, Eds. Beijing: Encyclopedia of China Publishing House.

Zhang, W. P., Zhang, Z. H., Shen, F. J., \& Yue, B. S. (2005). Mitochondrial D-Loop and NADH Dehydrogenase Subunit 5 (NDS) Gene of Panthera tigris amoyensis, P. tigris altaica and P. tigris tigris and Their Application in Phylogenetic Analysis. Sichuan Journal of Zoology, 24, 22.

Engels (1979). On Housing Problem. Marx and Engels Anthology (pp. 538-539). Vol. 2, Beijing: Renmin Press.

Chen, N. X. (2004). Jingjifa Li Xing Lun Gang (p. 85). Beijing: China Procuratorate Press.

In General, The Micro Process Is the Side Reflection of the Macro Evolution of Law. 
Due to Some Historical Reasons, It Wasn’t Carried out Formally.

The Chinese Net (2015). The White Paper of Socialist Legal System with Chinese Characteristics. http://www.npc.gov.cn/npc/xinwen/2011-10/28/content_1677859.htm

Merryman, J. H. (1984). The Civil Law Tredition (p. 94). Translated by P. D. Gu and Z. P. Lu, Eds. Beijing: Knowledge Publishing House.

Zhuo, Z. Y. (1998). Jurisprudence (p. 95). Beijing: Law Press.

Niu, Z. Z. (2007). On the Status of Scientific Department Law in Our Law System-Concurrently Discuss the Timely Comprehension of the Division Standard of Traditional Law Department. Science-Technology and Law, 5, 9-15. 